\title{
CURANDEIROS PARINTINTINE BENZEDEIRAS: REPRODUÇÃO DO SABER POPULAR DE CURA
}

\section{HEALERS PARINTINTIN AND BENZEDEIRAS: REPRODUCTION OF THE POPULAR KNOWLEDGE OF HEALING}

\author{
Maximillian Ferreira Clarindo \\ Doutor em Geografia pelo Programa de Pós-Graduação em Geografia - UEPG \\ maxclarindo@hotmail.com \\ Juliano Strachulski \\ Doutor em Geografia pelo Programa de Pós-Graduação em Geografia - UEPG \\ julianomundogeo@gmail.com \\ Nicolas Floriani \\ Professor Doutor do Programa de Pós-Graduação em Geografia - UEPG \\ florianico@gmail.com
}

\begin{abstract}
RESUMO
O presente artigo tem por objetivo geral discutir os saberes relacionados à cura de doenças, movimentados em um contexto de modernidades múltiplas, por benzedeiras localizadas na região sul do Brasil e por indígenas Parintintin localizados ao norte, no Estado do Amazonas. Fala-se de uma outra abordagem de saúde e doença a partir da Geografia, em uma perspectiva híbrida e holística da percepção das ausências e emergências destes atores. São saberes distantes do logocentrismo, que articulados por comunidades tradicionais ou de forma autônoma por benzedeiras urbanas ou rurais representam um importante aporte cultural do Brasil. O saber-fazer dos Parintintin incorpora signos não indígenas na mesma medida em que as benzedeiras envolvem simbolismos modernos com suas tradições. Tratam-se, portanto, de saberes e práticas que possuem base cognitiva semelhante e que vão se metamorfoseando ao longo dos anos, organizando por e através deles outras experiências espaciais, além das tracionadas pelas instituições. De maneira resiliente enfrentam seus diferentes algozes na perpetuação de seus saberes e modos de vida.
\end{abstract}

Palavras-chave: Parintintin. Benzedeiras. Geografia da saúde.

\begin{abstract}
The objective of this article is to discuss the knowledge related to the cure of diseases, moved in a context of multiple modernities, by benzedeiras located in the southern region of Brazil and by indigenous Parintintin located to the north, in the State of Amazonas. There is talk of another approach to health and disease from Geography, in a hybrid and holistic perspective of the perception of absences and emergencies of these actors. They are distant knowledge of logocentrism, which articulated by traditional communities or autonomously by urban or rural benzedeiras represent an important cultural contribution of Brazil. The know-how of the Parintintin incorporates non-indigenous signs to the same extent that the benzedeiras involve modern symbolisms with their traditions. They are, therefore, knowledge and practices that have a similar cognitive basis and that have been metamorphosed over the years, organizing through and through them other spatial experiences, beyond those drawn by institutions. In a resilient way they face their different executioners in the perpetuation of their knowledge and ways of life.
\end{abstract}

Keywords: Parintintin. Wound heels. Health geography.

Recebido em: 08/05/2019

Aceito para publicação em: 10/06/2019 


\section{INTRODUÇÃO}

O presente artigo tem por objetivo geral discutir os saberes relacionados à cura de doenças, movimentados em um contexto de modernidades múltiplas, por benzedeiras localizadas na região sul do Brasil e por indígenas Parintintin ao norte do país. Ambos os conhecimentos tradicionais são realidades sociais que carregam uma profusão bastante híbrida de simbolismos e (i)materialidades que vão se transmutando ao longo dos anos, na medida em que se reproduzem na sociedade em que se inserem.

As benzedeiras são pessoas com papéis sociais de bastante relevância em quaisquer dimensões de cidades, estejam elas no espaço urbano ou rural. Comumente são mulheres, idosas e que dedicam exclusivamente suas vidas em prol de cuidar do próximo, em que pese existam algumas com outras ocupações e que nas horas vagas dedicam-se em abrir as portas de suas residências para receber indistintamente pessoas acometidas das mais diversas doenças e males, ou mesmo para socializar saberes e outras trocas sociais.

Partindo-se do pressuposto factual de que saúde e doença são conceitos socialmente construídos, isto é, variam conforme a respectiva cultura em que são discutidos, têm-se que os saberes das benzedeiras ou indígenas, embora preservem similitudes em suas gêneses cognitivas, se alteram também conforme a região, cultura (especialmente diante da miscigenação de povos do território brasileiro) e contexto socioeconômico em que estão sendo movimentados.

Dentre estes condicionantes que impõem variações aos saberes e comportamentos da sociedade, deve-se considerar, portanto, o peso do fator geográfico. Isto é, a localização geográfica é preponderante na formatação destes, sobretudo quando se fala de um contexto de modernidades múltiplas, cuja projeção de simbolismos e imaginários geográficos (modernos ou não) ocorre de forma heterogênea no espaço. Nesta esteira, o espaço geográfico tanto condiciona a vivência social como também é um reflexo destas ações ou mesmo dos processos cognitivos envolvidos com a vida em sociedade.

Em meio às diferenças culturais manifestadas por estes saberes, percebe-se que as benzedeiras costumeiramente têm seus saberes atrelados à uma experiência religiosa (CAMARGO, 2014). Em algumas observa-se uma plurireligiosidade (sobretudo dentre as mais novas) e em outras, uma base religiosa/espiritual centrada em um catolicismo popular, cuja matriz católica é adaptada com a inserção de outros signos, especialmente aqueles oriundos da natureza (plantas medicinais, águas benzidas, ceras de abelha, e outros de origem animal/vegetal).

As benzedeiras que exercem seus ofícios em territorialidades rurais mostram-se ainda mais conectadas à natureza, devido a proximidade e disponibilidade dos elementos naturais e as concepções culturais que sobre eles são estabelecidas. No entanto, as benzedeiras urbanas também valem-se de remédios caseiros e usos de materiais naturais em seus rituais de benzimento, fazendo em pequenas porções de suas residências canteiros para cultivar plantações de medicinais ou, em alguns casos observados, até mesmo compram em farmácias especializadas em produtos naturais e formulam os remédios a partir disso.

As benzedeiras e curandeiros Parintintin, devido ao contato ao longo do tempo com a sociedade envolvente, possuem uma concepção prática e espiritual dos processos de cura, do manejo e da utilização de espécies vegetais, permeada tanto por elementos indígenas como da cultura não indígena. Apesar de viverem em meio a floresta Amazônica, também cultivam espécies vegetais em quintais e terreiros, além dos remédios da mata, na preparação de seus medicamentos, podendo inclusive, agregar os fármacos químicos, devido a presença da Farmácia da SESAI (Secretaria Especial de Saúde Indígena).

Em ambas sociedades, o conhecimento tradicional de cuidados com o corpo se estrutura em preceitos religiosos e possuem matrizes cognitivas bastante próximas. Flagrantemente, são formas desalinhadas do capital, cuja valoração se dá a partir do referenciamento/empoderamento social que ocorre com e através destes saberes. Fala-se aqui de outras racionalidades de troca, mesmo quando envolvem valores pecuniários - quando cobrar não é o mesmo que explorar economicamente.

A saúde (pública e coletiva) se encontra em meio aos mais evidentes problemas sociais do Brasil, cuja resolução parece distante e não restrita ao poder de ação governamental. Atualmente, a comunidade acadêmica em uma mirada mais abrangente de absorção de conhecimentos e o poder público (em menor escala) passaram a dar maior visibilidade a estes atores e seus respectivos

DOI:http://dx.doi.org/DOl 10.14393/Hygeia153148560 Hygeia 15 (31): $105-124$, Março/2019 página 106


saberes. Observam-se conjunturas sociais na região Sul do Brasil em que as benzedeiras passaram a ser parte integrante das políticas locais de saúde pública. Embora de forma modesta, a iniciativa representa lampejos de uma fértil parceria e um campo pouco explorado do ponto de vista acadêmico.

Desta forma, análise geográfica das benzedeiras e curandeiros indígenas alinha-se na necessidade de compreensão das matrizes cognitivas estruturantes deste "saber-fazer" e também contribui com a proposta epistêmica de valer-se da ecologia de saberes (SOUSA SANTOS, 2011) por intermédio da sociologia das ausências e emergências, na superação da crise do modelo civilizatório (política, econômica, social).

Em ambos os recortes espaciais, para aproximar-se dos atores sociais, primeiramente se fez uso da técnica da observação participante, em que o pesquisador interage com os sujeitos à medida que participa das atividades cotidianas (festas, trabalho, reuniões, rituais, etc.), fazendo perguntas, pedindo explicações, indicações e, também, trocando experiências e conhecimentos: dialogando (STRACHULSKI, 2018). De acordo com Albuquerque et al. (2010) esta metodologia permite uma análise de dentro da realidade estudada, possibilitando captar os conhecimentos desenvolvidos e aplicados no cotidiano.

Posteriormente, para investigar as benzedeiras da região Sul utilizou-se como método a história oral de vida e história oral temática (visando aprender sobre benzimentos), obtida através de entrevistas abertas, "[...] trata-se de um encontro, ou uma série de encontros face-a-face entre um pesquisador e atores, visando a compreensão das perspectivas das pessoas entrevistadas sobre sua vida, suas experiências, expressas na sua linguagem própria." (MACEDO, 2004, p.166). A história oral, conforme aponta Meihy (1996), privilegia depoimentos tornando-os centrais na análise.

$\mathrm{Na}$ abordagem aos Parintintin, ao identificar-se os primeiros informantes utilizou-se a técnica da "bola de neve" (ALBUQUERQUE et al., 2010). Assim, ao final de uma entrevista, o sujeito era instigado a indicar outra pessoa de interesse para a pesquisa. A técnica versa sobre o fato de que um informante-chave previamente conhecido (um contato local) seja instigado, ao final da entrevista, a indicar outra pessoa a ser entrevistada e, assim, sucessivamente, um entre vistado indica outro de interesse para a pesquisa. Portanto, a técnica consiste em selecionar dentre os membros da comunidade, e por indicação dos anteriores, aqueles que por iteradas vezes sejam recomendados como conhecedores locais (STRACHULSKI, 2018).

No caso dos Parintintin, avaliou-se ser mais eficiente realizar entrevistas semi-estruturadas, que possibilitam compreender as "[...] perspectivas que as pessoas entrevistadas têm sobre sua vida, suas experiências, sobre as instituições a que pertencem e sobre suas realizações, expressas em sua linguagem própria." (MACEDO, 2010, p. 105). A entrevista semiestruturada se caracteriza pelo fato de o pesquisador ter formulado perguntas antes de ter ido a campo e a partir de sua vivência poder alterar, retirar ou acrescentar perguntas até mesmo durante uma entrevista (ALBUQUERQUE et al., 2010).

Complementarmente, para aquelas dúvidas que permaneceram mesmo com a realização da entrevista semiestruturada, fez-se uso das conversas denominadas de entrevistas informais (GIL, 2008) ou entrevistas não estruturadas (ALBUQUERQUE et al., 2010), possibilitando uma visão geral acerca do problema de pesquisa.

Para tanto, divide-se esta pesquisa em dois momentos, sendo que inicialmente busca-se a inscrição de novas perspectivas geográficas através da valoração e análise de saberes situados fora do range acadêmico da atual geografia brasileira. Adiante, fala-se mais especificamente do contexto espacial de reprodução do saber das benzedeiras e dos curandeiros Parintintin.

O contexto social, político, econômico, cultural é imprescindível na compreensão das similaridades, origens, corpo estrutural e vêm somar com a afirmação de perspectivas geográficas mais híbridas, associadas ao novo paradigma das ciências sociais, no qual a Geografia tem assumido recentemente o papel de conciliadora, isto é, que agencia vários conhecimentos sob o prospecto espacial. 


\section{NOVAS PERSPECTIVAS GEOGRÁFICAS: ASPECTOS SOCIOCULTURAIS EM GEOGRAFIA DA SAÚDE}

Ao contrário dos curandeiros Parintintin que integram um povo indígena, as benzedeiras e os benzedeiros do sul do país localizam-se e desempenham seus labores de forma autônoma e fragmentada no espaço. Recentemente, há um intento de diferentes forças sociais (associação de moradores, secretarias municipais de assistência social, acadêmicos e outros interessados no assunto) em agrupar estes atores através do reconhecimento coletivo, facilitando a troca de informações, empoderamento a consequente manutenção deste saber tradicional.

Ainda assim, as diversas benzedeiras espalhadas pelo território, estruturam de maneira independente microterritórios em paralelo e por vezes intercruzados com as instituições e com a disponibilidade de serviços de saúde ofertados pelo Estado. Percebe-se, desta maneira, uma outra percepção do espaço geográfico, para além das "sociedades disciplinares" (como denomina FOUCAULT, 1999) e que extrapola os limites da ciência moderna. Considerando que "Em resumo, o pensamento científico, como o pensamento "popular" ou o "selvagem", escrevem ao longo do curso da história a narrativa de variações infinitas." (LAPLATINE, 2010, p. 45).

Em meio a estas alternâncias, subsistem no espaço geográfico, múltiplos atores sociais, encarregados de diferentes papeis da vida em comunidade, como as benzedeiras, cujas ações envolvem significações plurais para os diferentes públicos que buscam por estes conhecimentos. Em sentido amplo, as benzedeiras passam a atender diversas pessoas estejam elas próximas ou distantes. Isto ocorre em face de que seus trabalhos Ihes conferem um empoderamento social. Vislumbra-se que este empoderamento se dá, dentre outros fatores, pelo compartilhamento da linguagem entre a comunidade tributária destes saberes e as benzedeiras.

A oralidade é um dos traços mais evidentes deste saber-fazer, pois é através dela que os conhecimentos são repassados ao longo dos anos e por onde os semelhantes se reconhecem, já que a benzedeira é parte integrante da sociedade assim como o público que Ihe busca. Esta simplicidade facilita no reconhecimento e na compreensão de problemas que por vezes são mútuos. Neste sentido, acrescenta-se que:

A identificação da população, com os agentes da cura informais, revela, antes de tudo, um compartilhamento de linguagem ou identificação de classe social, fazendo com que tais práticas, persistam até hoje, arraigadas culturalmente, minando a base de qualquer argumento elitista e hierarquizante que delega às funções curativas populares, um papel menor e relacionado à ignorância. (ARAÚJO, 2011, p. 83).

Efetivamente, "[...] os curandeiros tradicionais são investidos por seu grupo de um poder exorbitante, por vezes mesmo superior àquele creditado ao médico diplomado." (LAPLATINE, 2010, p. 219). Por outro lado, contudo a pertinência social destes saberes, no plano acadêmico ainda se observa pouca atenção destinada em sua compreensão, quiçá pelo fato de que há certa dificuldade em avançar além dos limites cartesianos da ciência. Isto é, ainda que se busque suplantar a sistematização de estudos exigida e difundida no meio científico tradicional, acaba-se inevitavelmente por endereçá-los para tentativas de decifrar as coisas do mundo de maneira linear e/ou, então, como se fossem passíveis de serem moldáveis. Deve-se considerar, todavia, que conhecimentos tradicionais permanecem vivos e pujantes, mesmo nas sociedades urbanas modernas, ou como consigna Escobar:

É comum pensar que o comunal e o relacional são aplicáveis somente aos povos que mantiveram uma base territorial em sua existência, ou que ainda exibem práticas culturais que não são completamente modernas. No entanto, se adotarmos a posição de que a realidade é radicalmente relacional (como a ecologia, o budismo, a teoria dos sistemas, etc. assumem-na de maneira diferente), e que o chamado indivíduo não existe separado de outros seres humanos e não-humanos, esses princípios se aplicam a todo grupo humano, mesmo que seja diferente. É importante, portanto, começar a pensar seriamente sobre como reconstituímos a relacionalidade e a comunalidade nos ambientes urbanos e nos espaços mais marcados pela modernidade, mesmo entre aqueles grupos em que o regime cultural do indivíduo e do mercado penetrou mais profundamente ao nível dos imaginários e das práticas. (ESCOBAR, 2014, p. 59-60, tradução nossa).

Em outras palavras, em que pese o totalitarismo epistêmico das ciências modernas, como denomina Mignolo (2004), e da objetivação do modo de vida moderno, há outras configurações sociais na 
sociedade, ou seja, a globalização ao invés de esculpir um mundo homogêneo tem contribuído para ressurgimento e/ou dado maior visibilidade à antigas culturas e práticas. É o que Escobar (2014) denomina por "pluriverso", em que há muitos mundos coexistindo dentro daquele que se diz uno e hegemônico. Nestes termos, mesmo que a ciência intente avocar o papel de ser a "religião do mundo moderno" ou um ponto de chegada do conhecimento humano, deve-se considerar que há também outros saberes e conhecimentos inseridos na vida em sociedade, que não transcritos em livros e manuais. Outrossim, trabalha-se com a ideia de que "[...] os prefixos "científico" para os sistemas modernos e "anticientífico" para os sistemas tradicionais de saber têm pouca relação com o saber e muita com o poder." (SHIVA, 2002, p. 23).

Neste contexto, nuances sociais emergentes tendem a ocupar cada vez mais espaço na ciência (são as sociologias das ausências e emergências relacionadas por SOUSA SANTOS, 2011). Os saberes vernaculares situados até então do lado de fora dos muros acadêmicos (e também comumente ignorados pelas políticas públicas) passam a ganhar outra conotação que thes confere o status de igualdade perante o conhecimento dito científico. Em se tratando dos conceitos aqui discutidos (saúde e doença), percebe-se que as ciências sociais, como um todo, estão paulatinamente debruçando-se mais na questão, de sorte que preenchendo lacunas deixadas pela tecnificação da medicina (que é de inegável importância para a sociedade).

Mendonça, Araújo e Fogaça (2014) acrescentam que as abordagens interdisciplinares necessárias no trato da saúde pública e coletiva podem valer-se da Geografia, já que esta articula elementos espaciais nas análises dos problemas de saúde. Trata-se de uma perspectiva imprescindível na compreensão dos fenômenos relacionados a cura e doença. Vale ressaltar que a Organização Mundial de Saúde (OMS) estimula abordagens amplas no trato de saúde e doença, sendo que o agrupamento de diferentes áreas do conhecimento passa a ser fundamental à demanda pelo bem-estar social.

No entanto, a Geografia brasileira tem tratado da questão de saúde e doença de forma pouco híbrida, mas via de regra associando doenças específicas com a questão espacial através de ferramentas de georeferenciamento/mapeamento (SIG), com destaque para a dengue (CLARINDO, 2019). Neste contexto, questões mais abstratas merecem maior atenção científica/geográfica, como as afetas ao saber-fazer de benzedeiras e povos indígenas relacionadas com o assunto em questão. $O$ grande desafio centra-se na dificuldade de interpretar as conexões e simbolismos que se abstraem destes conhecimentos populares, que são bastante variadas e que muitas vezes dialogam com questões sobre-humanas (intangíveis).

Tendo em vista a riqueza da heterogeneidade das práticas e cuidados com a saúde no âmbito da população brasileira, especialmente quando se trata do emprego de ervas, rezas, crenças, unguentos, etc. ressalta-se a lacuna existente neste campo do conhecimento no Brasil. A diferenciação entre a perspectiva biomédica/saúde pública (Modernidade) e a perspectiva vernacular (Tradição) nos cuidados com a saúde representam um grande desafio nos estudos de Geografia da Saúde no Brasil. A riqueza e complexidade deste campo constitui, ao mesmo tempo, uma excelente oportunidade para se conhecer, ao mesmo tempo, tanto a sociedade (visão antropológica) quanto a historicidade de suas estratégias de enfrentamento dos males que a acometem ao longo dos tempos. Que os geógrafos a ele se dediquem com a maior brevidade possível...ganhará a ciência, ganhará a Geografia da Saúde, ganhará a sociedade. (MENDONÇA; ARAÚJO; FOGAÇA, 2014, p. 49).

Assim, fala-se aqui de um desafio aos rígidos moldes científicos, para além do esgotamento das discussões. Parte-se para outras abordagens destinadas a aproximação de práticas sociais invisibilizadas pelo poder dominante (seja ele político, econômico ou mesmo logocêntrico), em que a Geografia se firma enquanto uma ciência plural capaz de articular diferentes geografias e também outras áreas do conhecimento, alinhando ao mencionado por Amorim Filho (2006, p. 17) de que "No caso da história da Geografia, o que se observa quando a análise é cuidadosa, é uma atividade pluralista em todas as grandes etapas de sua formação." 


\title{
CONTEXTO ESPACIAL DE REPRODUÇÃO DO SABER DAS BENZEDEIRAS NO SUL DO BRASIL
}

Desde tempos coloniais a sociedade brasileira convive com a desigualdade social. Atualmente, o país é considerado o $10^{\circ}$ no ranking mundial de desigualdade $(\mathrm{RDH}, 2015)$. A história do país se dá a partir da dizimação dos povos indígenas por colonizadores, posteriormente por um longo período de escravidão e desde o Brasil república, sua trajetória contempla instabilidades econômicas, políticas (com uma frágil democracia), golpes de Estado, ingerências internacionais e outras mazelas que contribuem para acentuar ainda mais a desigualdade social no país, tal qual apontam Bartholo Jr. e Oliveira:

\begin{abstract}
O Brasil é uma sociedade com profundas desigualdades sociais e econômicas, cujos atuais índices de urbanização e industrialização convivem com uma estrutura fundiária perversamente concentrada e relações sociais e políticas herdadas do passado colonial e escravista. O país experimentou, segundo OLIVEN (2001), "uma modernização conservadora em que o tradicional se combinou com o moderno, a mudança se articulou com a continuidade e o progresso vive com a miséria". No Brasil, o processo de construção das identidades sociais forjou-se na imposição do modelo civilizatório ocidental, num embate contínuo entre as investidas de dominação e os processos de resistência cultural de comunidades e etnias nãohegemônicas. (BARTHOLO JR; OLIVEIRA, 2008, p. 2).
\end{abstract}

Abstrai-se disso que o conflituoso processo de configuração da sociedade brasileira só poderia resultar em múltiplas identidades na sociedade. Concomitante à imposição de uma identidade una (tentada ou imaginada) através da globalização, dos fluxos migratórios de europeus e até mesmo por interesse do Estado (em padronizar o país de acordo com a sazonalidade de seus interesses), a identidade brasileira foi se moldando através do agenciamento de parte destas pressões exógenas com outros símbolos e formas de viver e habitar no e com o espaço, herdados de indígenas (em um passado mais distante), mas também de povos africanos (adquiridos durante o período escravista) e de migrantes europeus vindos ao país no século passado.

Soma-se a estes principais componentes de formação identitária, o fato de que o Brasil é um país de dimensões continentais, de modo que há inevitáveis regionalismos em termos de identidade alinhados a uma infinidade de fatores. Assim, se estrutura a sociedade brasileira, uma verdadeira mistura de culturas que entrelaçam suas identidades nos signos da modernidade em um fluxo constante. Prova disso é a persistência de saberes tradicionais de cura (benzimentos) que resistem aos avanços tecnológicos da medicina ocidental.

Por meio dos manuscritos do Padre Anchieta se têm os primeiros registros de uso de plantas medicinais no Brasil. Naquela época, o conhecimento dos indígenas foi propagado através dos jesuítas para a população local e também para Portugal (FIGUEREDO, 2007 apud BORGES, 2011). Já no período colonial, há registros de que se praticavam formas alternativas de cura no Brasil, quando havia dificuldade na importação de remédios de Portugal e escassez de médicos. Para tanto, as curandeiras e benzedeiras da época manejavam plantas nativas e também exóticas (provenientes da África e de Portugal) na elaboração de remédios caseiros. (ARAÚJO, 2011; LORENZI e MATOS, 2002).

Araújo (2011) aponta que já no período colonial os curandeiros representavam à Coroa Portuguesa um "mal necessário", haja vista que cumpriam o importante papel de cuidar da saúde da sociedade. No entanto, eram desacreditados pelos poucos médicos da época. Neste contexto, sugere-se que sempre houve uma mácula envolvente ao conhecimento tradicional de saúde convivendo par e passo com uma infinidade de tributários deste saber. Assim, ao longo dos anos as bezendeiras conseguiram manter suas tradições, mesmo com inúmeras tensões e preconceitos lhes rodeando.

Com um forte enraizamento histórico nas mais diferentes culturas, a visão mágicoreligiosa ainda exerce muita influência nas formas de pensar a saúde e a doença na sociedade contemporânea. De um lado, o uso disseminado de chás, o recurso às rezas, benzeduras, simpatias, oferendas e os ritos de purificação, presentes nas diversas crenças e religiões (católica, evangélica, espírita, candomblé entre outras), atestam a força de sua presença na cultura brasileira. De outro, salienta-se a importância de reassociar as dimensões espiritual e ambiental às tradicionais dimensões social, biológica e psicológica em que se insere a vida humana (LUZ, 2006 apud BATISTELLA, 2007, p. 30-31). 
A benção, de um modo geral integra o cotidiano das famílias brasileiras afeiçoadas com alguma religião. Não é incomum observar o neto pedir ao avô/avó uma benção de mãos arrumadas, ou pais abençoando filhos, padres abençoando seus fiéis, dentre outros. No entanto, fala-se aqui de um benzimento ritualizado, em que há um objetivo e um encontro específico para tal (proteger, curar, etc.) e a incorporação de outros elementos além da imposição das mãos. (figura 1).

Figura 1 - Elementos utilizados por benzedeiras brasileiras.

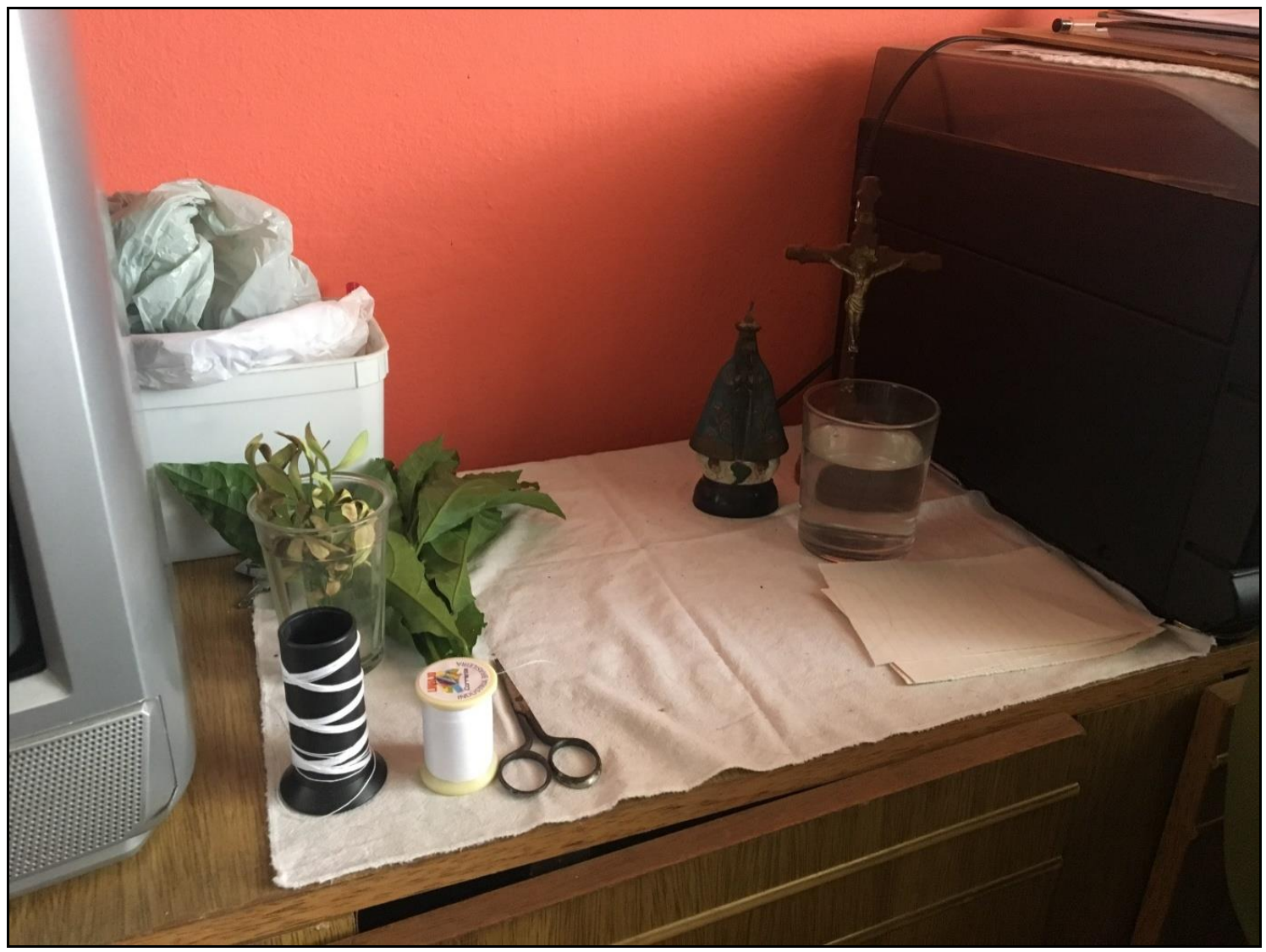

Fonte: CLARINDO, 2016.

Por meio da figura acima se percebe a variedade de componentes que envolve o saber-fazer das benzedeiras. O barbante auxilia a benzedeira a detectar com o auxílio da água o que está acontecendo com a pessoa, passando o barbante pelo tórax do paciente e cortando os fios sob o copo com água, então, a benzedeira vê como ficam dispostos os fios e através de uma leitura enigmática lança seu diagnóstico. A imagem religiosa no canto superior direito da imagem aponta para a Santa na qual a benzedeira é devota (Nossa Senhora Aparecida - padroeira do Brasil). Junto disso, há um ramo de planta medicinal que descortina um modo específico de dialogar com a natureza, presente na maioria das práticas das benzedeiras da região Sul do país.

A natureza possui valor singular para as benzedeiras, tal qual ocorre com os povos tradicionais, como os originários. "Os povos tradicionais, em geral, afirmam que, para eles, a "natureza" não é somente um inventário de recursos naturais, mas representa as forças espirituais e cósmicas que a vida é o que ela é." (POSEY, 1996, p. 150). Há uma distinta conexão das benzedeiras com a natureza, em que plantas são ressignificadas e seus valores transcendem a eficácia enquanto remédio caseiro. Algumas plantas passam a ter, nos rituais e remédios caseiros, um poder mágico. Para tanto, é necessário que se aprenda a manipular tais ervas da maneira correta, haja vista que mesmo tratando-se de plantas, há contraindicações de uso e aspectos nocivos em casos de manipulação equivocada. 
A manipulação correta dos remédios caseiros não raras vezes envolve rituais de preparação, que personificam um momento mágico. De acordo com Mauss, "O mágico é o homem que, por dom, experiência ou revelação, conhece a natureza e as naturezas; sua prática é determinada por seus conhecimentos. É aqui que a magia mais se aproxima da ciência." (MAUSS, 2003, p. 112).

A entonação mágica das plantas, destinadas à cura de enfermidades, proteção ou ao bem-estar das pessoas é uma realidade mesmo no meio urbano, conforme se observa na figura 2. Algumas benzedeiras preservam em suas residências plantações de remédios que servem tanto para consumo próprio como para a socialização com as pessoas do bairro ou da região em que atuam.

Figura 2 - Plantações de ervas medicinais em uma residência urbana de Ponta Grossa, PR.

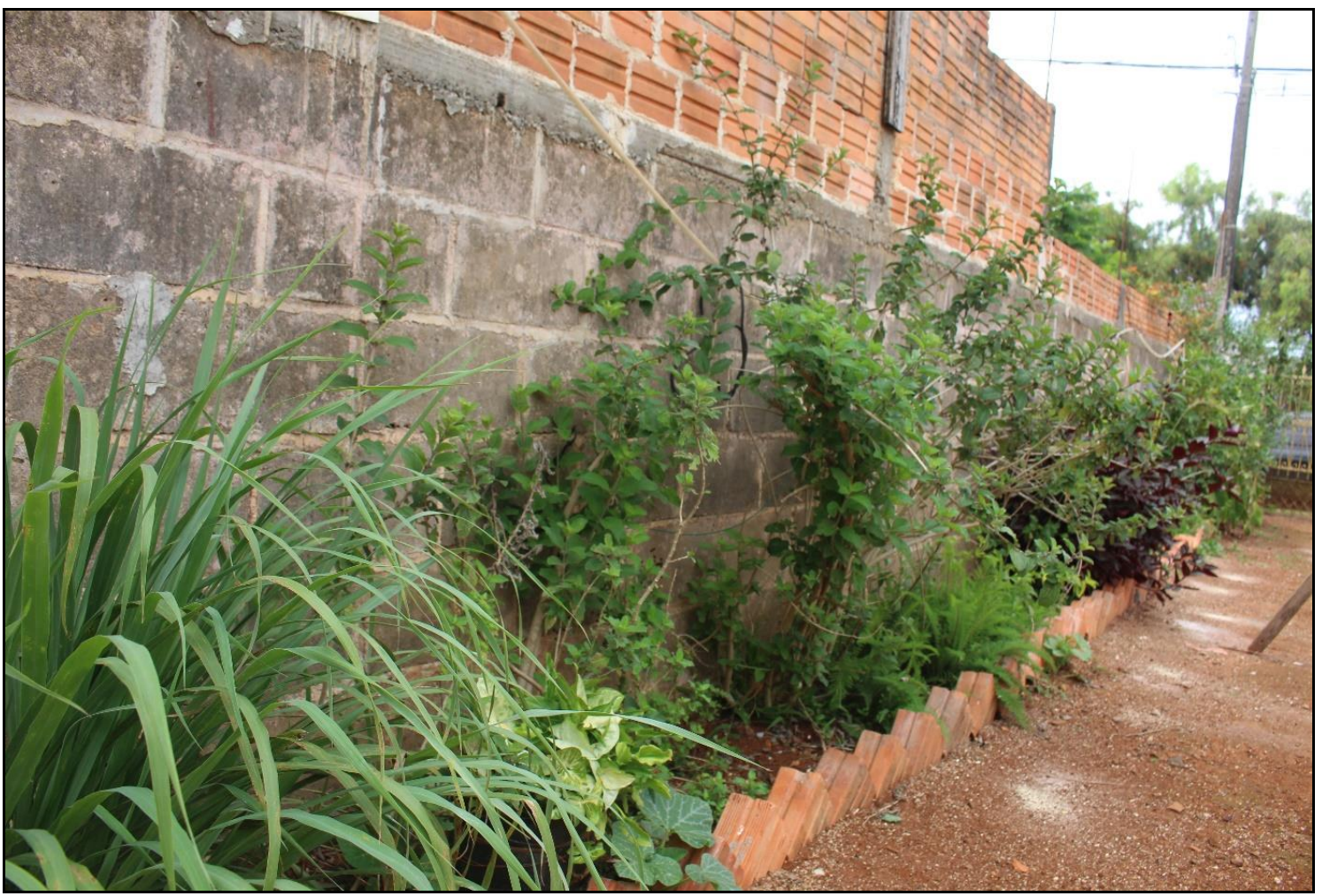

Fonte: CLARINDO, 2019.

Além do manejo de plantas, transformando-os em remédios, percebe-se que o saber das benzedeiras é formado a partir de uma infinidade de simbolismos e do agenciamento de diferentes culturas (com destaque para a indígena, africana e de migrantes europeus). Desta maneira, é inevitável também o encontro de diferentes religiões e crenças neste saber, conforme se observa na figura 3 , extraída de uma entrevista realizada com uma benzedeira urbana no município de Ponta Grossa, no estado do Paraná no ano de 2018.

A figura acima demonstra alguns signos associados com a religião Umbanda, como Zé Pilintra, lemanjá, Indígenas, Pretos Velhos, mas também imagens católicas como Nossa Senhora Aparecida, além de uma fotografia de Doutor Leocádio, guia espiritual associado à religião Espírita. Nestes termos, observa-se que não há uma unicidade religiosa nestes saberes, apesar da religião predominante no país ser a católica, já que atualmente o Brasil possui mais de $60 \%$ de sua população declarando-se católica. (IBGE, 2010). 
Figura 3 - Altar de uma benzedeira urbana de Ponta Grossa PR.

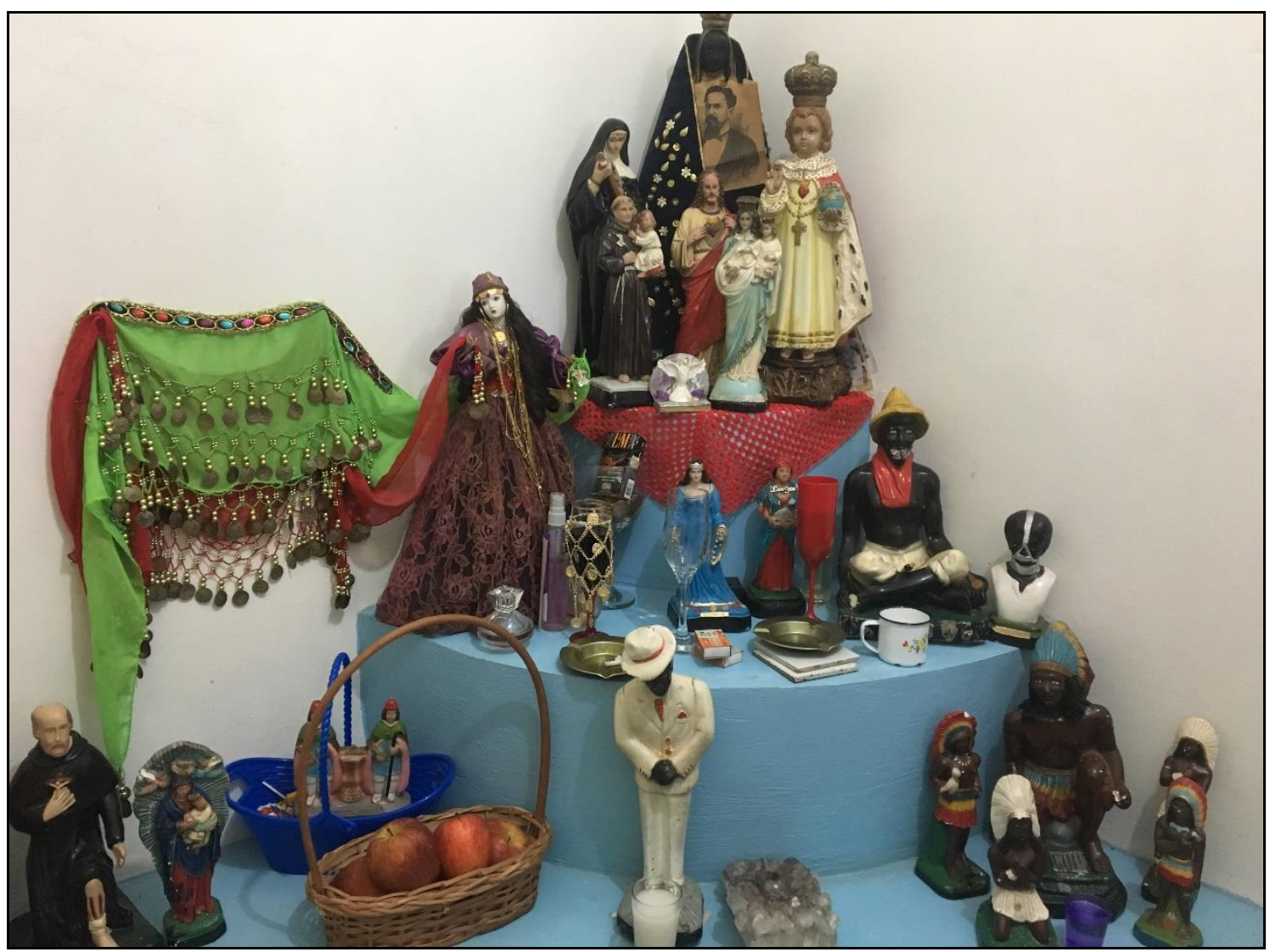

Fonte: CLARINDO, 2018

Ainda assim, há outras inúmeras formatações religiosas, algumas convivendo de forma bastante velada na sociedade, como é o caso das religiões de matriz africana, destacadamente a Umbanda e o Candomblé, em face do preconceito instaurado, até mesmo por outras denominações que inculcam em seus fiéis o repúdio a outras crenças e valores espirituais. A plurireligiosidade apresentada pelas benzedeiras aponta para outra formatação religiosa e espiritual da vida em sociedade, na qual as igrejas não são os únicos "marcadores territoriais" (termo cunhado de ALMEIDA SILVA, 2010), tampouco, as detentoras do capital de fé e de cura na sociedade. Zulian avalia que isto deve-se ao fato de que:

A pretensa unidade e organicidade conquistadas pela Igreja mascaram a multiplicidade de apropriações do catolicismo entre os próprios membros da instituição, ocultando uma variedade de compreensões e vivências da ortodoxia, de doutrina, de liturgia, técnicas, prédicas, cura de almas e uma grande diversidade de experiências religiosas. Essa multiplicidade pode ser estendida para os embates cotidianos, seja ele no interior dos movimentos e associações nas paróquias, na "leitura" das devoções por parte da população, na imprensa e outros órgãos de divulgação ou até mesmo nas múltiplas ocasiões de resistência às práticas reformadas. Pois os indivíduos sempre conseguem preservar espaços de liberdade, marcados muitas vezes pela transgressão e rebeldia, burlando o institucional, reinventando-o, e transitando por posições distintas, inclusive na esfera religiosa. (ZULIAN, 2009, p. 57).

As benzedeiras em atuação no espaço urbano de Ponta Grossa (Paraná) apresentam diferentes manifestações religiosas envolvidas em seus ofícios, que fazem correspondência às principais etnias que atuaram na construção identitária brasileira: indígenas, povos de origem africana e migrantes europeus. A figura a seguir (4) demonstra alguns utensílios utilizados por uma benzedeira que se disse descendente de índios que habitavam a região rural de Castro, PR, na região dos Campos Gerais. 
Figura 4 - Utensílios utilizados em benzimentos.

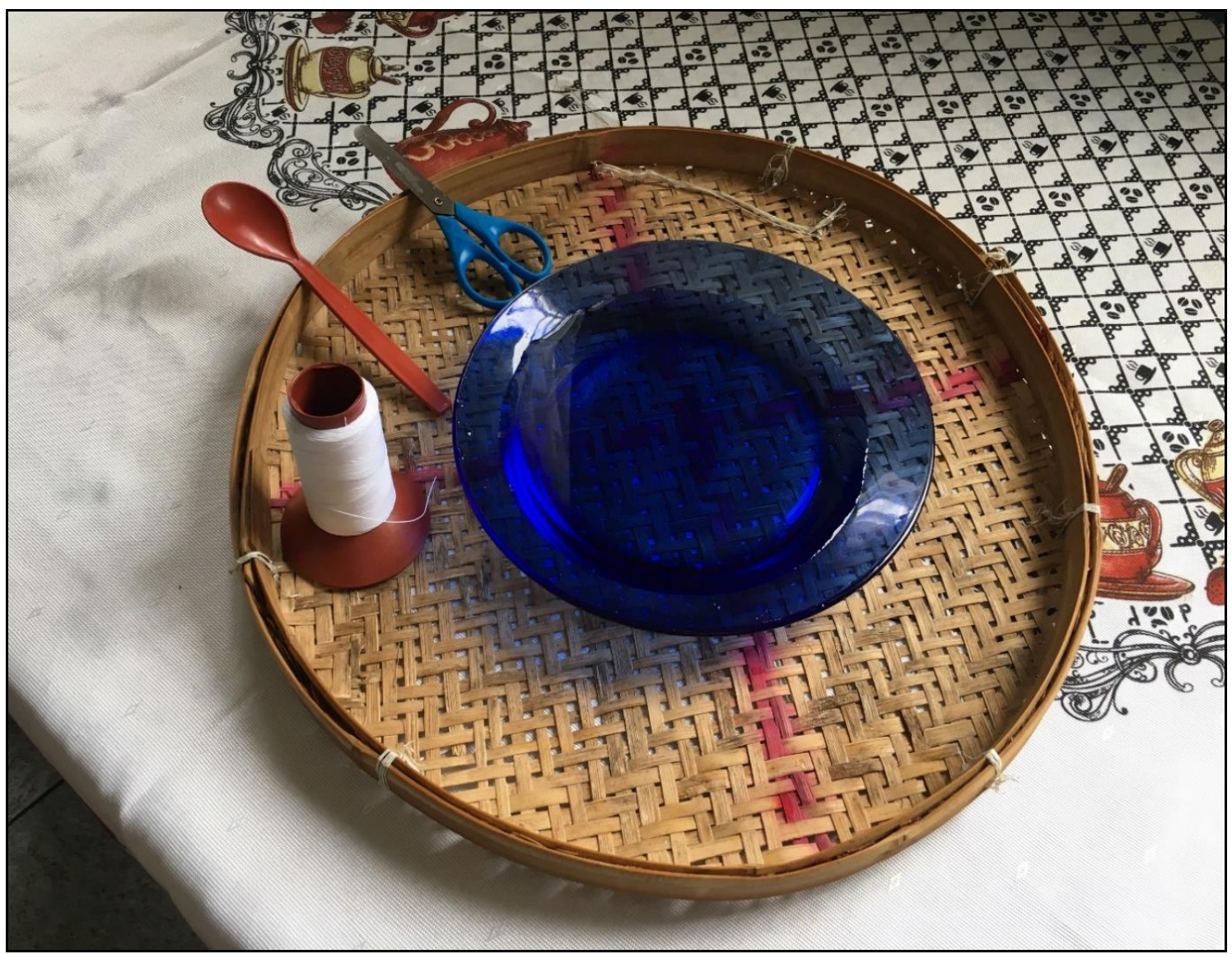

Fonte: CLARINDO, 2019.

O ritual através da peneira ocorre da seguinte forma: com o paciente já posicionado, a benzedeira mede as costas, ombros, pescoço, pernas, região superior da cabeça e faz uma cruz com a linha branca sobre o prato com água. $O$ prato deve estar posicionado bem ao centro da peneira, no cruzamento das linhas vermelhas (figura anterior). Em seguida, ela posiciona o carretel no centro do prato com o fio esticado, pronto para ser cortado.

Ulterior, a peneira é posicionada sobre a cabeça da pessoa, quando a benzedeira vai movimentandoa para as costas, depois voltando em direção ao tórax e por todo o restante do corpo. Ao encerrar o benzimento, é comum que se recomende os remédios caseiros adequados ao consumo, para complementar o tratamento.

Dentre as ervas recomendadas pelas benzedeiras comumente aparecem a Espinheira Santa (Maytenus ilicifolia), Cavalinha (Equisetum), Erva Cidreira (Melissa officinalis), Hortelã da Índia (Mentha arvensis L.), Alecrim (Rosmarinus officinalis), Melhoral (Justicia pectoralis Jacq. var. stenophylla Leonar), Losna (Artemisia absinthium) e outras. São plantas que quando não estão disponíveis em seus quintais ou na floresta (benzedeiras rurais), elas recomendam que sejam comprados em lojas de "produtos naturais", conforme os que aparecem na figura 5. Percebe-se, então, uma reificação no uso destas plantas, em que seus usos são adaptados de acordo com a disponibilidade. 
Figura 5 - Ingredientes comprados para elaboração de remédios caseiros.

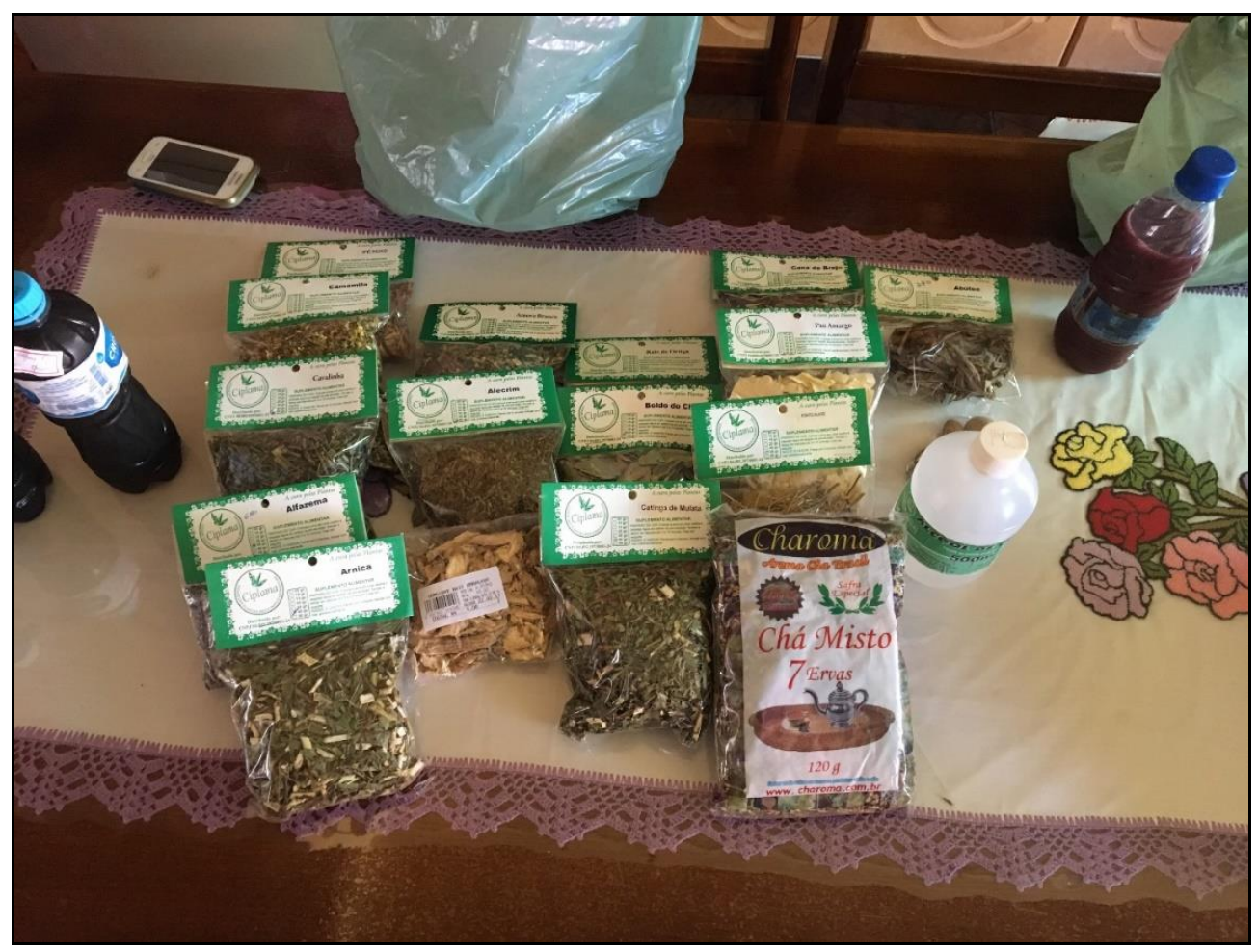

Fonte: CLARINDO, 2016.

Neste caminhar, o saber-fazer das benzedeiras é organizado na região por uma profusão de simbolismos materiais e imateriais, religiosos e profanos, que sustentam, além dos rituais de cura e proteção, um encorpado aporte cultural que dá sentido à vida de uma infinidade de pessoas da região. Assim, as benzedeiras com suas práticas, estejam elas no meio urbano ou rural, apregoam outros referenciais espaciais para a sociedade através de suas residências.

A partir de seus saberes, forma-se uma rede de reciprocidade social que age como um elemento de territorialização (e consequente formação de identidades) bastante incisivo. Inicialmente, há a configuração de microterritórios tradicionais a partir de suas próprias residências, considerando suas plantações de medicinais e outros simbolismos e adereços que comumente possuem nestes espaços.

Suas residências, então, tornam-se, além de um lugar para se morar, um ponto de referência para a sociedade ao redor (com certa característica sacra acentuada), ou seja, lugar de socorro social para as mais diversas doenças e angústias. Concomitante a isso, quando se observam as benzedeiras urbanas, percebe-se que elas imprimem nestas espacialidades um resquício de um passado rural, traduzido pela presença de geossímbolos tradicionais (varandas com medicinais/alimentares, hortas comunitárias, pequenas capelas com imagens de santas/os, etc.). São formas de habitar com e no espaço que coloca em órbita modernidade e tradição, pondo-se a questionar a velha dualidade urbano/rural, instaurando um verdadeiro conflito de imaginários geográficos.

As conexões estabelecidas e movimentadas pelas benzedeiras entre saúde e território, modernidade e tradição, avanços e permanências, (im)permeabilidades, são uma frutífera amostra do quão importante é o papel das ciências sociais na compreensão destas práticas em jogo. Além disso, a análise a partir da territorialidade envolvente destes sujeitos contribui para se compreender a firmação destes saberes no atual contexto global.

Pensa-se que a manutenção destes saberes, contudo os evidentes símbolos modernos que rodeiam a sociedade (mesmo as rurais e indígenas - no caso dos Parintintin) encontram um lastro tanto cultural, como social e econômico. Ou seja, em sentido ampliado, possuem como base de estruturação de seus conhecimentos os valores abaixo sintetizados: 
(a) antropológica, por resgatar os saberes populares e, assim, elevar a autoestima de populações, muitas vezes marginalizadas;(b) pedagógica, por permitir a instituição de uma relação dialógica entre trabalhadores de saúde e usuários que dominam os usos destas plantas medicinais;(c) econômica, permitindo o acesso ao medicamento fitoterápico;(d) ecológica, garantindo a manutenção de plantas que em muitas situações vêm sendo eliminadas pelas plantações com interesse meramente lucrativo. (CARRICONDE, 2002 apud GOMES e MERHY, 2011, p. 12).

Em um segundo momento, através desta demarcação territorial, as benzedeiras acabam por formar uma rede de amplitude não mensurável através do empoderamento que lhes é conferido pela prática de seus conhecimentos. Isto é, estes agentes alcançam e rompem barreiras geográficas e não raras vezes percebe-se no discurso delas que são visitadas por pessoas que moram até mesmo em outros continentes, além dos benzimentos à distância que são bastante comuns. Mesmo no contexto de modernidades múltiplas estes atores se mantêm ativos na sociedade, pois há uma memória social envolvendo os benzimentos, fazendo-as resistir ao tempo de maneira resiliente.

As benzedeiras, portanto, estão longe de ter um fim. Suas presenças até os dias atuais descortinam tanto a riqueza cultural e espiritual da sociedade brasileira quanto a fragilidade e desigualdade da sociedade. De um modo geral, elas agem com destacada importância também no recobrimento de lacunas deixadas pela oferta de saúde pública pelo Estado, bem como, como mantenedoras de uma riquíssima cultura, que talvez não pode ser encontrada em nenhum outro país com tamanho hibridismo de formas e sustentações.

\section{BENZEDEIRAS E CURANDEIROS PARINTINTIN E A REPRODUÇÃO DE SEUS SABERES NA ATURALIDADE}

A reprodução dos saberes Parintintin - localizados na Terra Indígena Nove de Janeiro, Humaitá - AM -, sobre espécies vegetais medicinais e formas de cura de males do corpo e da alma, se dá em seu território ancestral, pois, tais atores sociais e seus saberes estão localizados dento de um sistema cultural e de um território.

Como destacado anteriormente acerca do processo de constituição de identidades, cabe frisar que os povos indígenas, ao longo do tempo, têm se ressignificado devido ao contato e trocas culturais realizadas com a sociedade não indígena. Nessa perspectiva, ocorre um hibridismo cultural, em que processos ou fenômenos socioculturais distintos e que não se mesclavam, passam a se combinar e formar algo novo, diferente de antes da combinação, surgindo novas práticas, estruturas ou objetos (CANCLINI, 2008). Ao mesmo tempo que há o hibridismo, também ocorre o fortalecimento de práticas, saberes e crenças tradicionais.

Neste sentido, entende-se que os saberes e costumes tradicionais Parintintin proporcionaram uma relativa resistência às práticas da sociedade envolvente, sendo que seu sistema cultural se adaptou, internalizando novas práticas materiais e imateriais híbridas. Portanto, o manejo da natureza e a reprodução de seus saberes, apesar de ter sofrido com influências externas, é guiada por um conhecimento tradicional. A partir desse saber é que conseguem identificar a existência de moléstias.

Assim, compreendem que a doença pode se referir tanto aos distúrbios orgânicos promovidos por agentes biológicos que precisam ser expulsos, bem como de personificações espirituais, cujos elementos presentes no corpo do hospedeiro representam materialmente a ação de espíritos, no caso Parintintin, os anhanğ. Como infere Vianna (2012, p. 217), a doença para os indígenas seria o resultado de "[...] um desequilíbrio amplo, social e cósmico, envolvendo várias ordens, que encontra sentido justamente na existência da alteridade, ou seja, no conflito com os 'outros' - humanos e nãohumanos - que fazem surgir às doenças".

O tratamento das doenças pode ocorrer tanto por meio do uso prático de espécies vegetais, como seu uso simbólico, mediante benzimentos. Deste modo, as espécies vegetais manipuladas pelos indígenas podem ser tanto de origem natural, encontradas na floresta (primária ou secundária), como plantadas em quintais, forma de manejo adquirida da sociedade não indígena.

Os Parintintin utilizam as plantas no seu cotidiano, principalmente a folha, raiz, casca, etc., para a elaboração de chás, xaropes, realização de benzimentos e outras formas de manipulação, com respeito a maneiras particulares de preparo, além de possuírem suas contraindicações. 
Compreendem que em algumas situações as pessoas não podem fazer uso de certos medicamentos com riscos à saúde, como no caso das mulheres grávidas, podendo provocar o aborto.

O conhecimento tradicional sobre espécies vegetais de uso medicinal é fruto de uma sobreposição de diversos elementos, inerentes tanto ás suas concepções práticas como simbólicas. Sua constituição se dá a partir de processos e atributos sensíveis, que a princípio parecem estar desconexos, mas que comportam uma complexa inteligibilidade do mundo. Ele tem a capacidade de se reconstruir e ressignificar à medida que os cenários mudam.

Vários são os problemas de saúde tratados, dentre estes: gripes, sistema digestório, trato genitalurinário e doenças infecciosas (malária). As plantas podem ser utilizadas sozinhas ou em conjunto, destinadasa uma ou mais enfermidades. A maioria das espécies manejadas possuem usos práticos como a aplicação de óleo de Copaíba (Copaifera multijuga Hayne) e de Andiroba (Carapa guianensis Aubl.) através de massagens para tratamento de lesões.

Porém, com a presença da farmácia da SESAI, os Parintintin utilizam-se de fármacos químicos junto às plantas medicinais e/ou os remédios da floresta. Os fitoterápicos, no tratamento de moléstias, mostram-se muito frequentes e eficientes, sendo legitimados, transmitidos entre gerações e compartilhados no cotidiano.

A partir da convivência com os pressupostos culturais não indígenas, as práticas tradicionais são ressignificadas em novas práticas (materiais e imateriais) híbridas, referentes tanto à forma de preparo e ingestão do medicamento como o modo de aquisição das espécies vegetais, que podem ser encontradas na mata (de forma natural) e nos quintais (plantadas). Segundo Santos (2000, p. 926), na Amazônia as plantas de uso medicinal "[...] representam um importante ponto de encontro entre permanências e rupturas culturais, permitindo a observação de diferentes tradições de uso".

Os quintais (geralmente cercados - Figura 6) implantados pelos indígenas, uma herança cultural adquirida da sociedade envolvente, revelam-se uma boa fonte de espécies medicinais utilizadas pelos Parintintin. Diferente das espécies da floresta, são cultivadas em áreas próximas as suas casas. Normalmente, são ambientes de domínio das mulheres, mas de conhecimento dos homens também. Por outro lado, as matas são de domínio quase que exclusivo dos homens.

Figura 6 - Quintal cercado com espécies vegetais de uso medicinal

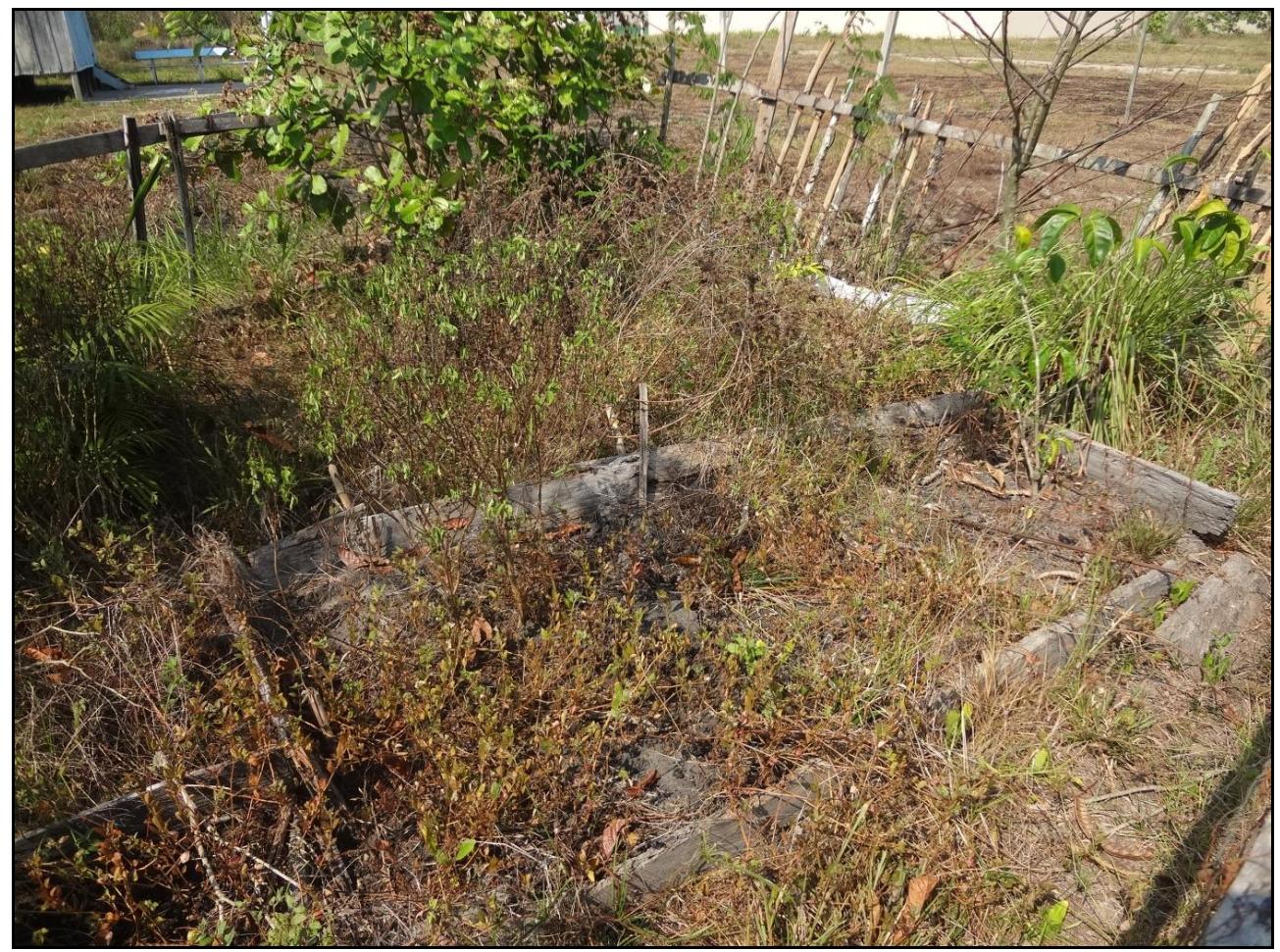

Fonte: STRACHULSKI, 2015. 
Ao longo do tempo os povos originários acabaram incorporando elementos culturais externos. Para tanto,buscam reequilibrar o que foi perdido. Agregam ao seu complexo sistema cognitivo-cultural práticas e conhecimentos modernos, os quais se metamorfoseiam e hibridizam elementos, que se percebem claramente na vida cotidiana, caracterizado pelo manejo de espécies vegetais para uso medicinal (CANCLINI, 2008; STRACHULSKI; FLORIANI, 2013a).

Há uma cosmovisão comum relacionada ao mundo vegetal de que as espécies vegetais podem auxiliar no tratamento, tanto de doenças físicas como simbólicas e espirituais. Desta forma, há plantas que são indicadas para a cura do organismo e outras para tratar das doenças de sua alma, como contra mau-olhado, quebranto, venta caída, feitiço (aruav), para o espírito do morto não perturbar os vivos e para proteção. Pois, "Paralelo a prática empírica, geralmente vem subjacente todo um sistema de crendices e ritos vinculados ao emprego das plantas que perdem a visão objetiva do cientista" (ALBUQUERQUE, 1997, p. 7, grifo nosso).

No tocante a proteção espiritual, há, em especial, duas espécies da cultura não indígena, manejadas pelos Parintintin e encontradas em alguns quintais locais e/ou plantadas próximas as suas casas, que são a Arruda (Ruta spp.) (Figura 7) e a Gibóinha (Sansevieria spp.) (Figura 8), mais conhecida como Espada-de-são-jorge. Tal assertiva é constada por Strachulski e Floriani (2013b) quando estudaram uma comunidade rural do sul do Brasil, entendendo que para os moradores ela repele as energias espirituais negativas, atuando contra o mau-olhado.

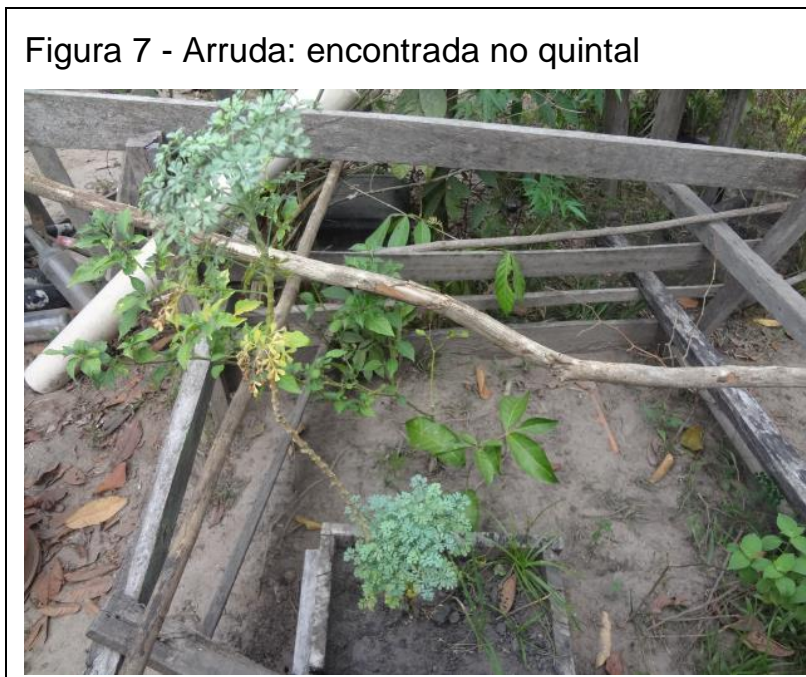

Fonte: STRACHULSKI, 2015.
Figura 8 - Gibóinha: plantada próxima a casa

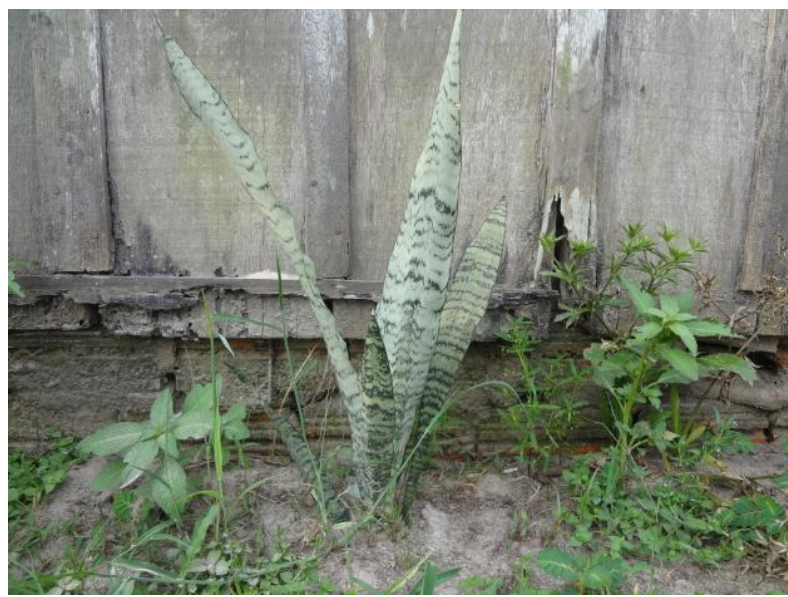

Fonte: STRACHULSKI, 2015.

Assim como há um hibridismo de formas de utilização prática das espécies vegetais, no tocante ao uso espiritual, também se vê um amálgama de possibilidades. Para tanto, há a procura dos moradores locais, tanto para receber benzimentos feitos por premissas da cultura indígena como não indígena.

As doenças do corpo naturalmente são tratadas mediante uso prático das espécies vegetais medicinais. Já as doenças espirituais (culturais) são tratadas a partir da realização de benzimentos. Esses são feitos em qualquer momento quando se trata de práticas não indígenas. Quando se referem aos indígenas, são pontuais e ocorrem em momentos especiais e com a utilização de Urucum (Figura 9), como se verifica em caso de falecimento. Logo, "[...] as espécies vegetais são objeto de conhecimento, de domesticação e uso, fonte de inspiração para mitos e rituais das sociedades tradicionais" (DIEGUES; ARRUDA, 2001, p. 11), possuindo uma importante função cultural, que é de reafirmar sua concepção de natureza. 
Figura 9 - Urucum (Bixa orellana L.): espécie da mata utilizada em benzimento

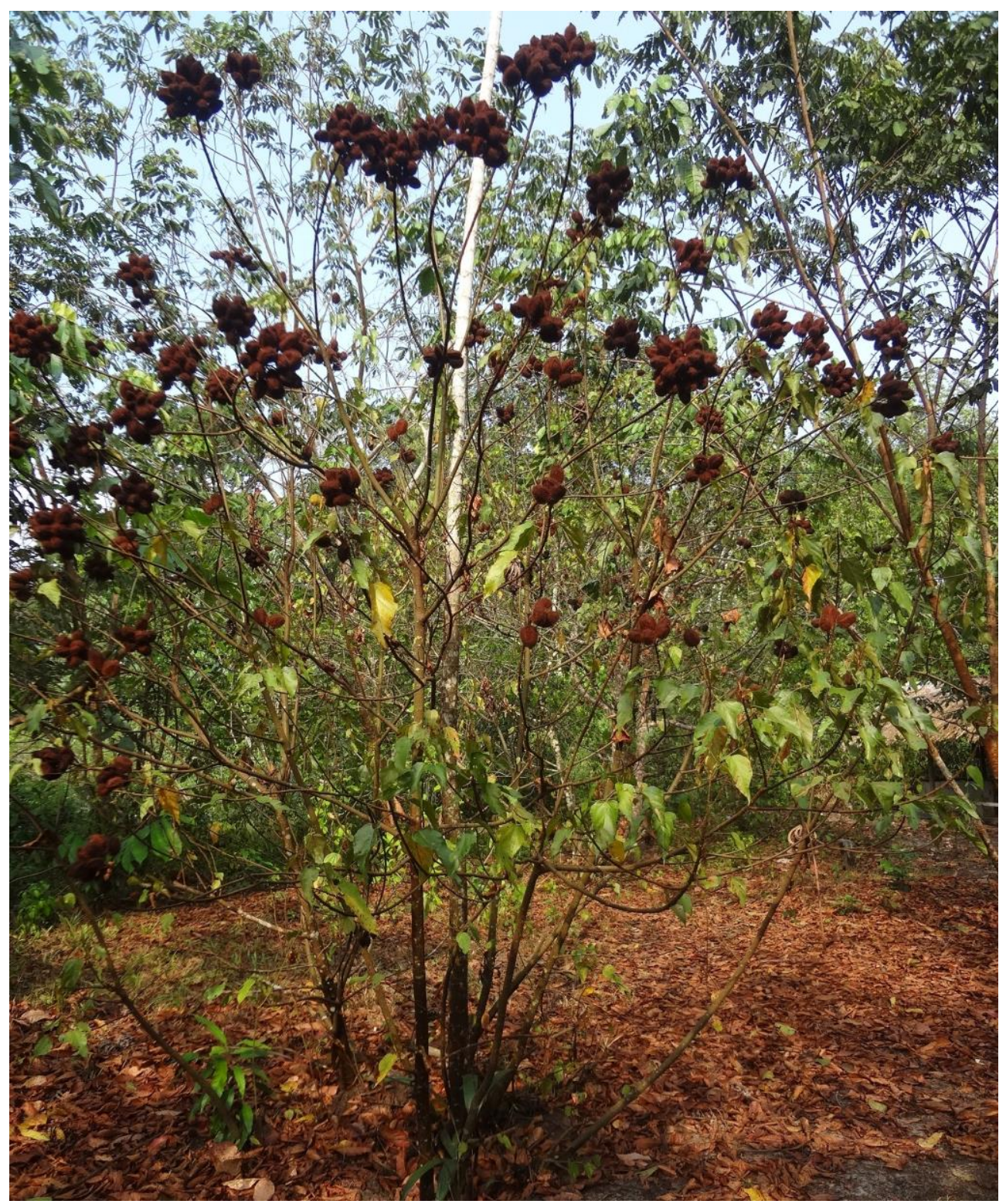

Fonte: STRACHULSKI, 2015.

Os benzimentos Parintintin são rituais que servem para a prevenção, proteção, cura de doenças, além de afastar os anhanğ (daqueles que morreram no local),que aparecem numa situação de fragilização espiritual, pois estes seriam espíritos dos mortos, bestas ou demônios, representando simbolicamente premissas negativas à saúde como desorientação, demência e morte (KRACKE, 1984). De forma complementar, Viveiros de Castro (2002) destaca que os espíritos se manifestam nas sociedadesindígenas a partir de relações com os indivíduos que se estabelecem pelas doenças.

Para amenizar a ação dos anhanğ é preciso realizar rezas e rituais provenientes dos saberes e do auxílio de espíritos elevados (demiurgos) que com seu poder cosmogônico e suas experiências territoriais inibem astutamente espíritos causadores de males e, consequentemente, orientam e promovem o fortalecimento espiritual e físico dos vivos (ALMEIDA SILVA, 2010).

Em relação aos rituais, há um próprio da cultura Parintintin, que ocorre devido ao falecimento de algum membro desse povo, no dia seguinte a morte. Para tal, uma benzedeira utiliza galhos de Urucum (Bixa orellana L.) e benze várias pessoas do povo indígena, no período da manhã, o que simbólica e espiritualmente tem o significado de proteger a saúde das pessoas e proporcionar 
juventude. O Urucum foi citado como uma planta que demora a morrer, logo, a pessoa benzida por esta planta, viverá mais. Ela acaba promovendo uma ação curativa e profilática, de caráter mágico (STRACHULSKI, 2018).

Além de proporcionar saúde, o benzimento também propicia libertar o espírito do falecido do plano terreno, impedindo-o de aparecer para os vivos. A benzedeira passa as folhas, principalmente, no rosto das pessoas idosas e jovens, bem como nas pernas, braços, costas, etc., como que se estivesse expulsando de perto 0 anhanğ.

A cura da doença mediante rezas e benzimentos ocorre a partir do proferimento de palavras e gestos, que podem ser considerados mágicos, capazes de alcançar um diálogo com o desconhecido e expulsá-lo. Tal ritual de cura atuaria de forma imunológica contra as entidades sobrenaturais e naturais, causadoras de doenças, mortes, e demais formas de moléstias (SANTOS, 2007).

A eficácia simbólica da cura ocorre quando acaba se estabelecendo uma consonância entre a estrutura mental, que dialoga com a estrutura espiritual e física (corporal) do indivíduo, em que a partir do (re)equilíbrio de uma dessas estruturas a outra se altera e também encontra um estado de equilíbrio. Ela,

[...] consistiria precisamente nessa 'propriedade indutora' que possuiriam, umas em relação às outras, estruturas formalmente homólogas que podem se edificar com materiais diversos nos vários níveis do vivente: processos orgânicos, pensamento inconsciente, pensamento consciente (LÉVISTRAUSS, 1975, p. 233, grifo nosso).

O tipo de benzimento mencionado se constitui como uma forma de linguagem, uma comunicação com o anhanğ, a partir da manipulação de elementos simbólicos como o Urucum, que se refere à prosperidadeem saúde. O manuseio de tais símbolos permite que o problema seja interpretado, significado, tratado e a saúde (física e espiritual) restabelecida.

Diferentemente das concepções moderno-científicas que separam o biofísico, o humano e o sobrenatural, é culturalmente inteligível que para os povos indígenas e sua concepção de natureza os eventos simbólicos como rituais, rezas e benzimentos façam parte de todos os momentos de sua vida de forma integrada, em especial,quando se trata da cura de enfermidades, que podem afetar corpo, mente e alma. "O ser humano é, ao mesmo tempo, natural e sobrenatural: pensamento, consciência e cultura se diferenciam e se confundem ao mesmo tempo, com a natureza viva e física" (FLORIANI, 2000, p. 99).

Os povos indígenas apresentam uma qualidade singular de ressignificar e reconstruir seus saberes acerca das espécies medicinais e rituais utilizados para curar enfermidades e/ou afastar maus presságios, num processo dinâmico e em perpétua evolução, realizam trocas com outros saberes que podem ser complementares e/ou conflitantes.

Com isso, incorporam e aceitam também os benzimentos feitos pelos não indígenas, pois se verifica que há um curandeiro não indígena, casado com uma mulher Parintintin. Também existe indígena homem e mulher que realizam essa prática com preceitos derivados da cultura externa, havendo a procura para que estes também façam benzimentos tanto para os próprios indígenas quanto aos moradores de entorno.

Ao que se refere aos benzimentos com premissas não indígenas, normalmente os benzedeiros utilizam folhas de uma espécie popularmente conhecida na região por Vassourinha (Scoparia dulcis L.), que é passada, na parte do corpo que se encontra debilitada, no sentido horizontal e vertical. Para tanto, o curandeiro indígena e o não indígena fazem o sinal da cruz e proferem palavras que contemplam sua reza - e que não podem ser reveladas para outrem -, o que está relacionado aos valores do cristianismo católico, refletindo, portanto, a hibridização de práticas culturais e espirituais.

O vegetal também é passado do corpo para fora, com o sentido e o objetivo de expulsar a dor e o problema, como no benzimento realizado por preceitos indígenas. Durante as rezas, normalmente ambos curandeiros podem passar a planta no corpo e no prato com água e sal e, após o término da reza, jogar tudo fora, ou utilizar somente a planta (benzer seco).

Alguns indígenas podem, inclusive, possuir algo que se assemelha a um altar (Figura 10), mas não necessariamente conforme aos dos benzedeiros e curandeiros não indígenas. Pois, apesar desse processo intenso de convívio com não indígenas e suas práticas culturais (materiais e imateriais), os

DOl:http://dx.doi.org/DOl 10.14393/Hygeia153148560 Hygeia 15 (31): 105 - 124, Março/2019 página 120


Parintintin revelam uma relativa incorporação de seus preceitos religiosos. Como a imagem a seguir retrata, não há uma preocupação de reservar um espaço que seja só de imagens, visto que junto a ela há aparelhos eletrônicos, além de não haver uma diversidade no tocante a esses símbolos.

Figura 10 - Retrato do que pode ser entendido como um altar de benzedeira Parintintin

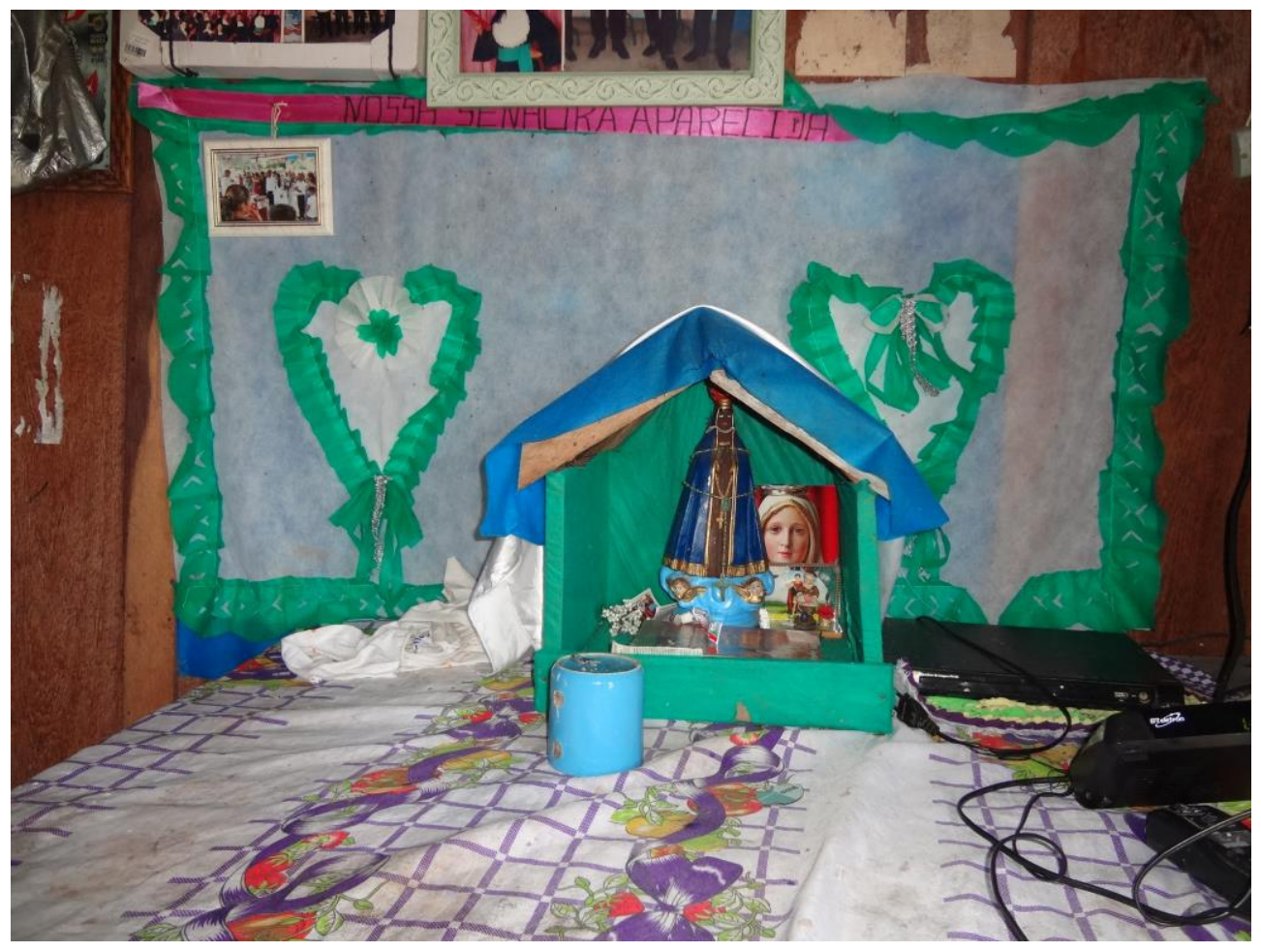

Fonte: STRACHULSKI, 2017.

Como constatado por Santos (2007) com os Enawene-Nawe e em outros estudos (ALBUQUERQUE, 1997; AMOROZO, 2002; ALMEIDA SILVA, 2010; STRACHULSKI; FLORIANI, 2013a), entre os Parintintin os conhecimentos sobre as práticas de cura e a utilização de espécies vegetais são transmitidos ao longo do tempo, entre as gerações e as famílias, incorporando preceitos não indígenas (benzimentos e construção de quintais) e da medicina moderna (fármacos químicos).

\section{CONSIDERAÇÕES FINAIS}

A análise do saber-fazer das benzedeiras urbanas e rurais da região sul do país e também das benzedeiras e curandeiros imersos em uma comunidade indígena ao norte do país apontam para proximidades cognitivas em suas bases. Mesmo quando estes saberes estão inseridos em comunidades indígenas percebe-se que há uma profusão de simbolismos que não estritamente relacionados com a cultura indígena.

Ao passo que as benzedeiras do Sul apresentam seus saberes também incrementados por diferentes signos, modernos ou vernaculares, religiosos ou não. Em meio a esta amplitude de formas, destacase a presença de simbolismos indígenas em um contexto urbano, como a peneira e o ritual praticado pela benzedeira (descendente de povos originários).

Portanto, o que há de mais comum em ambos sistemas culturais, no tocante aos saberes de cura é que sua reprodução ocorre num diálogo com outras formas de cognição, em um processo híbrido e em perpétua evolução, a partir da incorporação de elementos de outras culturas, como símbolos, práticas (materiais e imateriais) e conhecimentos. Estes também se mostram resilientes e operantes em ambas as sociedades, mesmo no contexto de modernidades múltiplas, como a presença da SESAl entre os povos indígenas e os postos de saúde e hospitais no meio urbano.

DOl:http://dx.doi.org/DOl 10.14393/Hygeia153148560 Hygeia 15 (31): 105 - 124, Março/2019 página 121


Oportuno destacar também que nas duas formas culturais, os benzimentos não se restringem à cura de doenças. Para os indígenas, há uma divisão entre doenças naturais e espirituais, sendo que as doenças do corpo (naturais) são tratadas mediante uso prático das espécies vegetais medicinais. Já as doenças espirituais (culturais) são tratadas a partir da realização de benzimentos. Esses são feitos em qualquer momento quando se trata de práticas não indígenas.

Já para as benzedeiras localizadas na região sul do país, o benzimento serve a doenças naturais e espirituais. Deve-se considerar também que há uma outra classe de problemas que também são enfrentados pelas benzedeiras, que são os de ordem sociais. Em síntese, os benzimentos acompanham os problemas da vida em sociedade, para tanto, há benzimentos para que a pessoa possa comprar um automóvel, possa prosperar no trabalho, consiga tirar a carteira de habilitação, etc. No que se refere ao uso de remédios caseiros pelas benzedeiras, percebe-se que estes estão conectados estritamente a doenças naturais do corpo humano.

Outro ponto comum encontrado entre as práticas é que algumas plantas medicinais são cultivadas em quintais, mesmo entre os Parintintin. Isto revela uma estratégia (ainda que inconsciente) de suplantar a dizimação de espécies, seja ela provocada pelo agronegócio e as monoculturas (comuns na região Sul) ou pela devastação das florestas que cercam os povos indígenas.

Desta forma, conclui-se que os saberes tradicionais relacionados saúde e doença sempre existirão, tanto como uma estratégia de resistência social e cultural, como de socorro à precariedade de serviços e políticas públicas da sociedade brasileira.

\section{REFERÊNCIAS}

ALBUQUERQUE, U. P. Plantas medicinais e mágicas comercializadas nos mercados públicos do Recife - PE. Ciência \& Trópico, Recife, v. 25, n. 1, p. 7-15, Jan./Jun., 1997.

ALBUQUERQUE, U. P.; LUCENA, R. F. P.; CUNHA, L. V. F. C. Métodos e técnicas na pesquisa etnobiológica e etnoecológica. 1. ed. Recife: NUPEEA, 2010. (Coleção Estudos e Avanços).

ALMEIDA SILVA, A. Territorialidades e identidade do coletivo Kawahib da Terra Indígena UruEu-Wau-Wau em Rondônia: "Orevaki Are" (reencontro) dos "marcadores territoriais". 2010. 301 f. Tese (Doutorado em Geografia) - Universidade Federal do Paraná, Curitiba, 2010.

AMOROZO, M. C. M. Uso e diversidade de plantas medicinais em Santo Antônio do Leverger, MT, Brasil. Acta BotanicaBrasilica, v. 16, n. 2, p. 189-203, 2002. https://doi.org/10.1590/S0102$\underline{33062002000200006}$

ARAÚJO, F. L. Representações de Doença e Cura no Contexto da Prática Popular da Medicina: Estudo de caso sobre uma benzedeira. CAOS - Revista Eletrônica de Ciências Sociais, Paraíba, v. 1, n. 18, p.81-97, set. 2011.

BATISTELLA, C. Saúde, Doença e Cuidado: complexidade teórica e necessidade histórica. In: FONSECA, A. F.; CORBO, A. D'A.; O Território e o Processo Saúde-Doença. Rio de Janeiro: EPSJV/Fio Cruz, 2007. p. 25-50.

BOM MEIHY, J. C. S. Manual de história oral. 4. ed. São Paulo: Edições Loyola, 1996. 78 p.

BORGES, V. C. Pequi, Jatobá, Algodãozinho...A biodiversidade do Cerrado na medicina popular. 2011. 273 f. Tese (Doutorado em Geografia). Universidade Federal de Goiás, Goiânia 2011.

CAMARGO, M. T. L. de A. A religiosidade na medicina popular. Revista Nures, Rio Claro - SP, n. 26., p. 1-8/2014.

CANCLINI, N. G. Culturas híbridas. Estratégias para entrar e sair da modernidade. 4. ed. 4. reimpr. Tradução de Ana Regina Lessa e Heloísa PezzaCintrão. São Paulo: Editora da Universidade de São Paulo, 2008.

CLARINDO, M. F. Medicina popular e comunidades rurais da Região da Serra das Almas, Paraná: o amálgama cosmo-mítico-religioso tradicional. 2014. 124 f. Dissertação (Mestrado em Geografia). Universidade Estadual de Ponta Grossa, 2014. 
A Geografia da cura e do sagrado: a resistência das benzedeiras no espaço urbano de Ponta Grossa. 2019. 179 f. Tese (Doutorado em Geografia). Universidade Estadual de Ponta Grossa, 2019.

DIEGUES, A. C., ARRUDA, R. S. V. (Orgs.). Saberes tradicionais e biodiversidade no Brasil. Brasília: Ministério do Meio Ambiente; São Paulo: USP, 2001. (Biodiversidade, 4).

ESCOBAR, A. Sentipensar com la tierra. Nuevas lecturas sobre desarrollo, território y diferencia. Medellín: Ediciones UNAULA, 2014. 184 p.

FOUCAULT, M. Vigiar e punir: nascimento da prisão. 20. ed. Petrópolis: Vozes, 1999. 288 p.

FLORIANI, D. Marcos Conceituais para o Desenvolvimento da Interdisciplinaridade. In: PHILIPPI JR., A; TUCCI, C. E. M.; HOGAN, D. J.; NAVEGANTES, R. (Eds.). Interdisciplinaridade em Ciências Ambientais. São Paulo: Signus Editora, 2000. p. 95-108.

GIL, A. C. Métodos e Técnicas de Pesquisa Social. 6. ed. São Paulo: Atlas, 2008.

IBGE. Censo demográfico. Rio de Janeiro: 2010.

KRACKE, W. H. Ivaga'nga, Mbahira'nga e Anhang: gente do céu, gente das pedras e demônios das matas (espaço cosmológico e dualidade na cosmologia Kagwahiv). Comunicação apresentada no Grupo de Trabalho Cosmologia Tupi. Brasília: XVI Reunião da ABA, 1984.

LAPLATINE, F. Antropologia da doença. 4. ed. São Paulo: Editora WMF Martins Fontes, 2010, 274 p.

LÉVI-STRAUSS, C. A eficácia simbólica. In: Antropologia estrutural. Rio de Janeiro: Tempo Brasileiro, 1975. p. 215-236.

LITTLE, P. E. Territórios Sociais e Povos Tradicionais no Brasil: Por Uma antropologia da territorialidade. Artigo. Brasília: UNB, 2002, 32 p.

LORENZI, H. E.; MATOS, F. J. de A. Plantas medicinais do Brasil: nativas e exóticas. Nova Odessa. São Paulo: Instituto Plantarum. 2002. 512 p.

MACEDO, R. S. Etnopesquisa crítica e multirreferencial nas ciências humanas e na educação. 2. ed. Salvador: EDUFBA, 2004. 297 p. https://doi.org/10.7476/9788523209353

Etnopesquisa crítica etnopesquisa-formação. 2. ed. Brasília: Liber Livro Editora, 2010.

MCDOWELL. L. A transformação da geografia cultural. 1996.

MERHY, E. E.; GOMES, L. B. Compreendendo a educação popular em saúde: um estudo na literatura brasileira. Cadernos de saúde pública. v. 27. n. 1. jan. 2011. p. 7-18. https://doi.org/10.1590/S0102-311X2011000100002

MENDONÇA, F; ARAÚJO, W. M.; FOGAÇA, T. K. A geografia da saúde no Brasil: Estado da arte e alguns desafios. InvestigacionesGeograficas, Chile, n. 48, p. 41-52, 2014. https://doi.org/10.5354/0719-5370.2014.36675

OLIVEIRA, E. R. de. Doença, cura e benzedura: Um estudo sobre o ofício da benzedeira em Campinas. 1983. Dissertação (Mestrado em Antropologia Social). Instituto de Filosofia e Ciências Humanas da Universidade Estadual de Campinas,1983

POSEY, D. A. Os Povos Tradicionais e a Conservação da Biodiversidade. In: Uma estratégia Latino-americana para a Amazônia. PAVAN, C. (Cord). São Paulo: UNESP, v.1, 1996, p.149-157.

SANTOS, F. S. D. Tradições populares de uso de plantas medicinais na Amazônia. História, Ciências, Saúde - Manguinhos, Rio de Janeiro, v. 6, supl., p. 919-939, set. 2000. Disponível em: <http://www.scielo.br/pdf/hcsm/v6s0/v6s0a08.pdf>. Acesso em: 3/05/2019.

https://doi.org/10.1590/S0104-59702000000500009

SANTOS, G. M. Esboço sobre cosmologia, doença, cura e cuidados nos Enawene-Nawe. In: FERREIRA, L. O.; OSÓRIO, P. S. (Orgs.). Medicina Tradicional Indígena em Contextos - Anais da I Reunião de Monitoramento. Projeto Vigisus II/Funasa. Brasília: Fundação Nacional de Saúde, 2007. cap. 8. p. 78-90. 
SHIVA, V. Monoculturas da Mente: Perspectivas da biodiversidade e da biotecnologia. São Paulo: Gaia. 2003. 240 p.

SOUSA SANTOS, B. Epistemologías del Sur. Utopía y Praxis Latinoamericana, Maracaibo Venezuela, n. 54, p. 17-39, jul./set. 2011.

STRACHULSKI, J.; FLORIANI, N. Conhecimento popular sobre plantas: um estudo etnobotânico na comunidade rural de Linha Criciumal, em Cândido de Abreu- PR. Revista Geografar, v. 8, n. 1, p. 125- 153, jun. 2013a. Disponível em: <http://revistas.ufpr.br/geografar/article/view/30327/20463>. Acesso em 15/08/2013. https://doi.org/10.5380/geografar.v8i1.30327

STRACHULSKI, J.; FLORIANI, N. Levantamento etnobotânico no meio rural do município de Cândido de Abreu - Estado do Paraná, Brasil. In: VI Congresso Internacional Sistemas Agroalimentares Localizados, 6., 2013, Florianópolis. Anais... Florianópolis: UFSC / CIRAD, 2013b, p. 1-20.

STRACHULSKI, J. Kagwyri pe jihoi: o território como fundamento do saber tradicional Parintintin na Aldeia Traíra da Terra Indígena Nove de Janeiro, Humaitá-AM. 2018. 337 f. Tese (Doutorado em Geografia) - Universidade Estadual de Ponta Grossa, Ponta Grossa, 2018.

VIANNA, J. J. B. De volta ao caos primordial: alteridade, indiferenciação e adoecimento entre os Baniwa. 2012. 258 f. Dissertação (Mestrado em Antropologia Social) - Universidade Federal do Amazonas, Manaus, 2012.

VIVEIROS DE CASTRO, E. B. A Inconstância da alma selvagem e outros ensaios de antropologia. São Paulo: Cosac Naify, 2002.

ZULIAN, R. W. Entre o aggiornamento e a solidão: práticas discursivas de D. Antônio Mazzarotto, primeiro bispo diocesano de Ponta Grossa - PR (1930-1965). 2009. 429 f. Tese. (Doutorado em História) - Universidade Federal de Santa Catarina, Florianópolis, 2009. 